Available online at GSC Online Press Directory

GSC Biological and Pharmaceutical Sciences

e-ISSN: 2581-3250, CODEN (USA): GBPSC2

Journal homepage: https://www.gsconlinepress.com/journals/gscbps

(RESEARCH ARTICLE)

\title{
Development and validation of simultaneous estimation of drugs in combination from pharmaceutical formulation by RP-HPLC method
}

Pooja Eknathji Waware ${ }^{1 *}$, Anuja Dattatriayji Jolhe ${ }^{1}$, Swati Rajendra Lilhare ${ }^{1}$, Dr. Prasad Prakash Jumade 2 and Dr. Dharmendra Ramgopalji Mundhada ${ }^{3}$

\author{
${ }^{1}$ Student of Master of Pharmacy, Department of Quality Assurance, Agnihotri College of Pharmacy, Wardha 442001, \\ Maharashtra, India \\ ${ }^{2}$ Faculty in Department of Quality Assurance, Agnihotri College of Pharmacy, Wardha 442001. Maharashtra, India \\ 3 Principal, Agnihotri College of Pharmacy, Wardha 442001, Maharashtra, India.
}

Publication history: Received on 14 September 2020; revised on 20 September 2020; accepted on 22 September 2020

Article DOI: https://doi.org/10.30574/gscbps.2020.12.3.0296

\begin{abstract}
Metformin is recommended as a first-line agent for monotherapy and combination therapy for patients with type 2 diabetes mellitus (T2DM). Patients whose glycaemic control deteriorates over time with metformin monotherapy will require additional anti-diabetic medication. The development of HPLC method for simultaneous estimation of antidiabetic drugs in combination from solid dosage form by HPLC method. To validate the developed HPLC method as per ICH guidelines. The System suitability test ,Capacity factor, Tailing factor, Resolution, Selectivity, Separation factor, Theoretical plates, Regression coefficient, STD for intercept, LOD (limit of detection), LOQ (limit of quantification, Repeatability, Precision studies (Intra-day and Interday/Intermediate), Linearity/Calibration studies, Robustness, Force degradation/Stability indicating studies, Specificity, Drug recovery/accuracy studies are performed. The system suitability test performed for saxagliptin and metformin hydrochloride has achieved all guideline criteria; including tailing factor $(T)$, separation factors $(\alpha)$, theoretical plates $(N)$, capacity factor $(k)$, resolution $(R)$ and RSD (\%), force degradation studies were also performed for both these drugs. So combinedly we concluded that the proposed reverse phase chromatographic (RP-HPLC) analytical method for the simultaneous estimation in both bulk and tablet formulation have complied the ICH and US-FDA guidelines.
\end{abstract}

Keywords: Saxagliptin hydrochloride; Metformin; RP-HPLC; Diabetes mellitus

\section{Introduction}

According to statements by the American Diabetes Association/European Association for the Study of Diabetes and the American Association of Clinical Endocrinologists/American College of Endocrinology, metformin is recommended (unless specifically contraindicated) as a first-line agent for monotherapy and combination therapy for patients with type 2 diabetes mellitus (T2DM). This recommendation is based primarily on metformin's glucose lowering effects, absence of weight gain, generally low level of side effects, and relatively low cost [1,2]. However, many patients, particularly those with higher baseline glycated haemoglobin (HbA1c) values, may not achieve their glycaemic goals on metformin monotherapy despite titration to maximally tolerated doses, and therefore require additional medication [1, 3 , 4]. Patients whose glycaemic control deteriorates over time with metformin monotherapy will require additional anti-diabetic medication. Although multiple classes of anti-diabetic agents are available, there remains a need for agents with different mechanisms of action that offer improved efficacy and/or better tolerability profiles and can be used

\footnotetext{
${ }^{*}$ Corresponding author: Pooja Eknathji Waware

Student of Master of Pharmacy, Department of Quality Assurance, Agnihotri College of Pharmacy, Wardha 442001, Maharashtra, India.
}

Copyright $(2020$ Author(s) retain the copyright of this article. This article is published under the terms of the Creative Commons Attribution Liscense 4.0. 
either as monotherapy or in combination treatment regimens (including metformin). Dipeptidyl peptidase-4 (DPP-4) inhibitors are a class of oral anti-diabetic agents that increase circulating concentrations of the incretin gastrointestinal hormones glucagon-like peptide-1 and glucose-dependent insulinotropic polypeptide [5]. The incretins are rapidly released after meals and stimulate glucose-dependent insulin secretion. Glucagon-like peptide-1 also inhibits glucagon secretion, thereby attenuating postprandial glucose excursions [6]. The DPP-4 inhibitors improve glycaemic control by blocking the rapid inactivation of incretins, mainly glucagon-like peptide-1 [7-12]. Sitagliptin (Januvia ${ }$, Merck \& Co, Inc, Whitehouse Station, NJ), the first of the DPP-4 inhibitors approved in the United States, has been used as an adjunct to diet and exercise in monotherapy and in combination regimens with other oral anti-diabetic drugs [1,11-13]. The mechanism of action of the DPP-4 inhibitors is complementary to that of metformin, which improves insulin sensitivity and reduces hepatic glucose production [5]. Hypoglycaemia, weight gain, and edema are generally not associated with DPP-4 inhibitor therapy; however, these adverse events have been associated with other anti- diabetic drug classes that are often used in conjunction with metformin (e.g. sulphonylurea, glinides, thiazolidinediones, and insulin) [6]. The low propensity for both DPP-4 inhibitors and metformin to cause hypoglycaemia or weight gain makes them an appropriate option for combination therapy in patients who are not meeting their glycaemic goals [5]. Saxagliptin (Onglyza TM, Bristol-Myers Squibb, Princeton, NJ/AstraZeneca, Wilmington, DE) is a potent, selective DPP-4 inhibitor, approved as an adjunct to diet and exercise to treat hyperglycaemia in patients with T2DM [14-16]. In phase 3 clinical trials, saxagliptin added to a stable dose of metformin, sulphonylurea, or thiazolidinedione, or given as initial therapy in combination with metformin, significantly improved glycaemic control and was well tolerated in patients with T2DM [7-9,17]. In a 24-week study in patients whose diabetes was not adequately controlled by stable metformin doses, adding saxagliptin $2.5,5$, or $10 \mathrm{mg}$ daily reduced HbA1c from a baseline of $8.1 \%$, by $0.7,0.8$, and $0.7 \%$, respectively, compared with add-on placebo [7].

\section{Material and methods}

The high performance liquid chromatography (HPLC) of Shimadzu SCL-10Avp inbuilt with binary pump (LC- 10ATvP), UV detector (SPD-10Avp), Rheodyne $20 \mu$ loop capacity manual injector (P/N 77251) was used throughout the analysis. The LC-Solution software was used to interpret the HPLC reports. UltraSil-MCX ${ }^{\circledR}, 5 \mu \mathrm{m} ; 100 \mathrm{x} 2.1 \mathrm{~mm}$ ID., column purchased from (Newcastle-UK) was used throughout the analysis. Digital weighing balance (ME-204) purchased from Mettler-Toledo (USA), ultra-sonicator Labman ${ }^{\circledR}$ purchased from UltraChrom Ltd, India. Digital pH meter from MettlerToledo was purchased from (Mumbai-India). $50 \mu$ micro-syringe was purchased from Hamilton USA. $0.20 \mu$ and $0.45 \mu$ nylon membrane filters were purchased from Phenomenex ${ }^{\circledR}$ Mumbai, India. Reagents used are HPLC grade methanol and deionised water were purchased from Merck (Mumbai, India). HPLC grade ammonium formate (AF) (99\%) was purchased from Merck Chemicals (Mumbai, England). 0.20 and $0.45 \mu$ nylon membrane filters were used and purchased from UltraChrom Innovatives Pvt. Ltd. (India). Saxagliptin standard was gifted from Mylan laboratories Ltd. (Hyderabad, India). Metformin standard was obtained from Sapkaal knowledge hub (Nashik, India). 20 tablets of Riax-M® XR, (saxagliptin- $5 \mathrm{mg}$ and metformin-500 mg), manufactured by Dr. Reddy's Laboratories Ltd. (India) were purchased from local pharmacy store. All other chemicals and reagents were used of analytical grade.

\subsection{Standard stock solution}

Standard stock solutions of SXP and MET (1 mg mL-1) were prepared separately by dissolving $10 \mathrm{mg}$ of the drug in methanol-water $(2: 1 \mathrm{v} / \mathrm{v})$ using a $20 \mathrm{~mL}$ volumetric flask and completing the final volume by adjusting with either methanol or water, based on their solubility in particular solvents. Furthermore, freshly prepared sample solution was sonicated for 10-20 minutes and filtered through $0.20 \mu$ nylon filters.

\subsection{Working stock solution}

The saxagliptin has low UV absorption and detectivity at lower UV radiation nearly at 200-230 nm, the working stock solution of SXP; $500 \mu \mathrm{g} \mathrm{mL-1}$ was prepared and by diluting $5 \mathrm{ml}$ of $1000 \mathrm{ppm}$ solution into 5 ml of blank volume with the mobile phase. Similarly, since the metformin has stronger UV absorbance, the working solution of MET (250 $\mu \mathrm{g} \mathrm{mL}-$ 1) was prepared by diluting $2.5 \mathrm{ml}$ of $1000 \mathrm{ppm}$ solution into the $7.5 \mathrm{ml}$ blank of the mobile phase.

\subsection{Chromatographic condition}

The ultraviolet detector was operated at $228 \mathrm{~nm}$ for saxagliptin and $235 \mathrm{~nm}$ for metformin to achieve to optimum absorbance level. The buffer solution was filtered through $0.2 \mu \mathrm{m}$ nylon membrane filter and degassed for $12 \mathrm{~min}$ in an ultrasonic bath prior to its use. The mobile phase was pumped through the column at a flow rate of $1 \mathrm{~mL}$ min-1. The column temperature was adjusted to $28{ }^{\circ} \mathrm{C}$ and the injection volume was $20 \mu \mathrm{L}$. 


\subsection{Sample preparation for accuracy/drug recovery studies}

Exactly 10 tablets of Riax-M® XR, were weighed separately, powdered and then mixed in a mortar. An accurately weighed $10 \mathrm{mg}$ of finely powdered Riax-M® XR $5 \mathrm{mg} / 500 \mathrm{mg}$ equivalent to $5 \mathrm{mg}$ of SXP and $500 \mathrm{mg}$ of MET were dissolved into $100 \mathrm{~mL}$ with methanol water and then sonicated until complete dissolved. The solutions were then filtered, followed by serial dilutions to the required concentrations using the mobile phase for each experiment including the standard addition technique.

\subsection{Linearity/Calibration studies}

Accurately measured aliquots of stock solutions, equivalent to $15.25-250 \mu \mathrm{g} \cdot \mathrm{mL}^{-1}$ and $32.15-500 \mu \mathrm{g} \cdot \mathrm{mL}^{-1}$ of SXP and MET, respectively were transferred separately into a series of $10 \mathrm{~mL}$ volumetric flasks. During each dilution, the volume was adjusted with same methanol-water; then $20 \mu \mathrm{L}$ of each diluent were injected into HPLC.

\subsection{Precision of the three methods}

Three replicates of similar concentrations of the mixture of SXP (500 ppm) and MET ( $\left.250 \mu \mathrm{g} . \mathrm{L}^{-1}\right)$ were analyzed three times, within the same day (intraday precision), using the procedure mentioned. Moreover, the mentioned concentrations of three replicates were analyzed on three successive days using the same procedure to investigate the intermediate 9inter-day) precision.

\subsection{Robustness for the chromatographic method}

The flow rate of the mobile phase was changed from $1 \mathrm{ml} \cdot \mathrm{min}-1$ to $1.2 \mathrm{~mL}^{\mathrm{min}}{ }^{-1}$ and $0.8 \mathrm{~mL} \cdot \mathrm{min}^{-1}$ to evaluate the effect of the flow rate; similarly the variation of organic modifier as methanol was changed from $83 \%$ to $83 \pm 2 \%$ to monitor the system suitability parameters Finally, the effect of wavelength was monitored by making deliberate variation for saxagliptin $(228 \pm 2 \mathrm{~nm})$ and for metformin $(230 \pm 2 \mathrm{~nm})$ and the differences in system suitability parameters such as peak tailing, capacity factor, resolution and theoretical plates were tested and evaluated.

\section{Results}

The sensitivity of saxagliptin was quite negligible at $220 \mathrm{~nm}$ as they have preferred to separate them on C18 column $[18,19]$. Hence, this simultaneous estimation proved effectively the separation of saxagliptin and metformine with acceptable resolution (R) and capacity factor (k) and significantly improved UV sensitivity at 228 and $235 \mathrm{~nm}$ wavelengths. Moreover, the complete separation was carried out within 8 minutes.

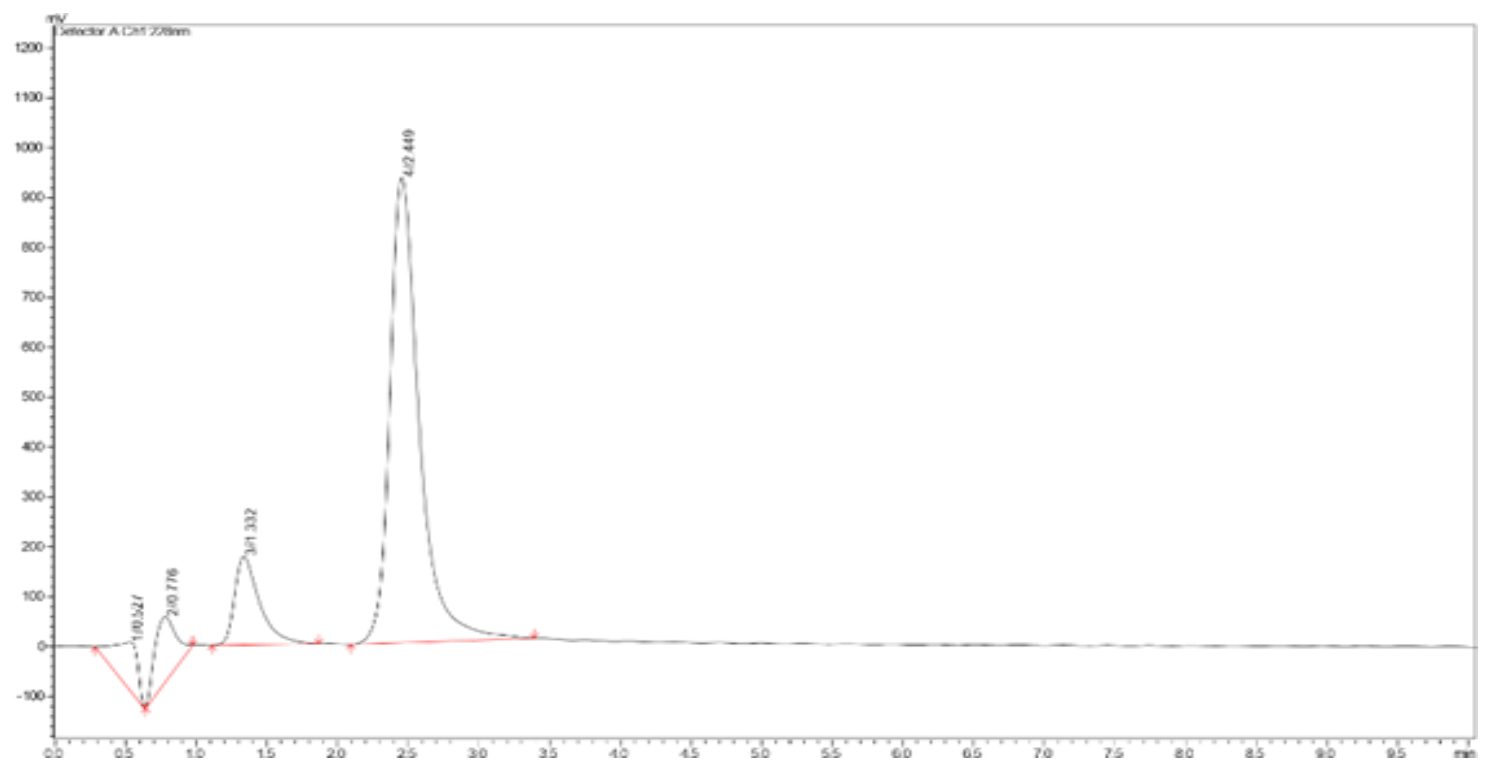

Figure 1 Method development reports of SXP (1.33) and MET (2.44) by RP-HPLC

During the optimization cycle, several columns were tried for the experiment, but the reverse phase HPLC column proved the best results with good peak sensitivity and symmetry, improved peak shape with enhanced resolution, selectivity and capacity factor, and importantly completed the whole analysis within eight minutes run time. Few 
chromatogram of method development of reverse phase column were shown in (figure 1) and finally separation carried out using $10 \mathrm{mM}$ ammonium format-methanol $(17: 83 \mathrm{v} / \mathrm{v})$ was selected.

\subsection{Method validation}

\subsubsection{Repeatability}

Implementing the procedure mentioned under section, the homologous mixture of both SXP and MET of same concentrations $\left(500 \mu \mathrm{g} \cdot \mathrm{mL}^{-1}\right)$, were tested for six injections within the same day. The \% RSD was calculated and found it is less than 2\%; shown in (Table 1).

Table 1 Repeatability data of SXP and MET

\begin{tabular}{|l|l|l|}
\hline S. No. & Saxagliptin ; 228 $\mathbf{~ m m ~}$ & Metformine; 235 $\mathbf{~ m}$ \\
\hline & Peak Area; Conc. $500 \mathrm{ppm}$ & Peak Area; Conc. 250 ppm \\
\hline 1 & 2340019 & 8332596 \\
\hline 2 & 2428726 & 8626274 \\
\hline 3 & 2319443 & 8259515 \\
\hline 4 & 2347548 & 8258027 \\
\hline 5 & 2331553 & 8207594 \\
\hline 6 & 2404107 & 8347476 \\
\hline Mean & 2361899 & 8338580 \\
\hline STD. DEV. & 43944.14 & 150186.66 \\
\hline RSD (\%) & 1.86 & 1.80 \\
\hline
\end{tabular}

\subsubsection{Precision}

SXP and MET of three replicates of three similar concentrations; $500 \mathrm{ppm}, 250 \mathrm{ppm}$ were tested and evaluated within the same day (intra-day precision). The \%RSD was calculated and found less than 2\%; shown in (Table 2).

Table 2 Intraday Precision data of SXP \& MET

\begin{tabular}{|c|c|c|c|c|c|c|c|}
\hline \multirow{2}{*}{ S. No. } & \multirow{2}{*}{$\begin{array}{l}\text { Concentratio } \\
\text { n (ppm) }\end{array}$} & \multicolumn{2}{|l|}{ Area } & \multicolumn{2}{|l|}{ Mean \pm SD } & \multicolumn{2}{|l|}{$\%$ RSD } \\
\hline & & SXP & MET & SXP & MET & SXP & MET \\
\hline \multirow{3}{*}{1} & $250 \mathrm{ppm}$ & 2340118 & 8259515 & \multirow{3}{*}{$\begin{array}{l}2329327 \pm \\
10411.42\end{array}$} & \multirow{3}{*}{$\begin{array}{l}8241712 \pm \\
29556.420 \\
27.42\end{array}$} & \multirow{3}{*}{0.44} & \multirow{3}{*}{0.35} \\
\hline & $250 \mathrm{ppm}$ & 2328521 & 8258027 & & & & \\
\hline & $250 \mathrm{ppm}$ & 2319342 & 8207594 & & & & \\
\hline \multirow{3}{*}{2} & $250 \mathrm{ppm}$ & 2347548 & 8258027 & \multirow{3}{*}{$\begin{array}{l}2361036 \pm \\
38254.03\end{array}$} & \multirow{3}{*}{$\begin{array}{l}8271032 \pm \\
70842.06\end{array}$} & \multirow{3}{*}{1.62} & \multirow{3}{*}{0.85} \\
\hline & $250 \mathrm{ppm}$ & 2331353 & 8207594 & & & & \\
\hline & $250 \mathrm{ppm}$ & 2404207 & 8347476 & & & & \\
\hline \multirow{3}{*}{3} & $250 \mathrm{ppm}$ & 2309140 & 8377515 & \multirow{3}{*}{$\begin{array}{l}2325910 \pm \\
14839.59\end{array}$} & \multirow{3}{*}{$\begin{array}{l}8310934 \pm \\
73109.84\end{array}$} & \multirow{3}{*}{0.63} & \multirow{3}{*}{0.87} \\
\hline & $250 \mathrm{ppm}$ & 2337341 & 8232696 & & & & \\
\hline & $250 \mathrm{ppm}$ & 2331251 & 8322591 & & & & \\
\hline \multicolumn{6}{|c|}{ Range of \%RSD } & $0.44-1.62$ & $0.35-0.87$ \\
\hline
\end{tabular}


The homologous mixture of both SXP and MET of three replicates of three different concentrations; $500 \mathrm{ppm}, 250 \mathrm{ppm}$ were tested and evaluated in three successive days (interday/intermediate precision). The \%RSD was calculated and found less than 2\%; shown in (Table 3).

Table 3 Interday (intermediate) Precision data of SXP \& MET

\begin{tabular}{|c|c|c|c|c|c|c|c|}
\hline \multirow{2}{*}{ S. No. } & \multirow{2}{*}{$\begin{array}{l}\text { Concentratio } \\
\text { n (ppm) }\end{array}$} & \multicolumn{2}{|l|}{ Area } & \multicolumn{2}{|l|}{ Mean \pm SD } & \multicolumn{2}{|l|}{ \%RSD } \\
\hline & & SXP & MET & SXP & MET & SXP & MET \\
\hline \multirow{3}{*}{1} & 250 ppm & 2440019 & 8454961 & \multirow{3}{*}{$\begin{array}{l}2419396 \pm \\
26547.49\end{array}$} & \multirow{3}{*}{$\begin{array}{l}8386309 \pm \\
73180\end{array}$} & \multirow{3}{*}{1.09} & \multirow{3}{*}{0.87} \\
\hline & $250 \mathrm{ppm}$ & 2428726 & 8309316 & & & & \\
\hline & $250 \mathrm{ppm}$ & 2389443 & 8394652 & & & & \\
\hline \multirow{3}{*}{2} & $250 \mathrm{ppm}$ & 2347548 & 8809306 & \multirow{3}{*}{$\begin{array}{l}2361069 \pm \\
38120.08\end{array}$} & \multirow{3}{*}{$\begin{array}{l}8882306 \pm \\
139673\end{array}$} & \multirow{3}{*}{1.61} & \multirow{3}{*}{1.52} \\
\hline & $250 \mathrm{ppm}$ & 2331553 & 8794260 & & & & \\
\hline & $250 \mathrm{ppm}$ & 2404107 & 9043353 & & & & \\
\hline \multirow{3}{*}{3} & $250 \mathrm{ppm}$ & 2309142 & 9161683 & \multirow{3}{*}{$\begin{array}{l}2315880 \pm \\
6168.94\end{array}$} & \multirow{3}{*}{$\begin{array}{l}9100344 \pm \\
135436\end{array}$} & \multirow{3}{*}{0.26} & \multirow{3}{*}{1.48} \\
\hline & $250 \mathrm{ppm}$ & 2309142 & 8945091 & & & & \\
\hline & $250 \mathrm{ppm}$ & 2317249 & 9194260 & & & & \\
\hline & & & & & & $0.26-1.61$ & $0.87-1.52$ \\
\hline
\end{tabular}

\subsubsection{Linearity}

Limit of detection (LOD) which represents the concentration of analyte at S/N ratio of 3.3 and limit of quantification (LOQ) at which S/N is 10 were determined and results are given in (Figure2 \& 3). Low values of LOD and LOQ indicate sensitivity of the applied method for determination of the mentioned drugs in tablets (Table $4 \& 5$ ).

Table 4 Linearity data of saxagliptin

\begin{tabular}{|c|c|c|c|}
\hline S. No. & $\begin{array}{l}\text { Concentration } \\
\left(\mu \mathrm{g} \cdot \mathrm{mL}^{-1}\right)\end{array}$ & Area & Average (Mean) \\
\hline \multirow[b]{2}{*}{1} & 500 PPM & 2533475 & \multirow[b]{2}{*}{2508338} \\
\hline & 500 PPM & 2483201 & \\
\hline \multirow[b]{2}{*}{2} & 250 PPM & 1262155 & \multirow[b]{2}{*}{1257637} \\
\hline & 250 PPM & 1253119 & \\
\hline \multirow[b]{2}{*}{3} & 125 PPM & 622160 & \multirow[b]{2}{*}{622160} \\
\hline & 125 PPM & ----- & \\
\hline \multirow[b]{2}{*}{4} & 62.5 PPM & 313907 & \multirow[b]{2}{*}{319544} \\
\hline & 62.5 PPM & 325182 & \\
\hline \multirow[b]{2}{*}{5} & 31.25 PPM & 160770 & \multirow[b]{2}{*}{159746} \\
\hline & 31.25 PPM & 158723 & \\
\hline 6 & \multicolumn{2}{|c|}{ Regression Equation } & $Y=5011.6 x+2487.4$ \\
\hline 7 & \multicolumn{2}{|c|}{ Correlation coefficient $\left(\mathrm{R}^{2}\right)$} & 1 \\
\hline 8 & \multicolumn{2}{|c|}{ Std. Error of intercept } & 3177.71 \\
\hline 9 & \multicolumn{2}{|c|}{ Std. Dev. of intercept } & 7105.57 \\
\hline 10 & \multicolumn{2}{|l|}{ LOQ } & $4.67 \mu \mathrm{g} \cdot \mathrm{ml}^{-1}$ \\
\hline 11 & \multicolumn{2}{|l|}{ LOD } & $14.17 \mu \mathrm{g} \cdot \mathrm{ml}^{-1}$ \\
\hline
\end{tabular}


Table 5 Linearity data of metformin

\begin{tabular}{|c|c|c|c|}
\hline \multicolumn{3}{|c|}{ Name of Drug; Metformine } & \multirow[b]{2}{*}{ Average (Mean) } \\
\hline S. No. & $\begin{array}{l}\text { Concentration } \\
\left(\mu \mathrm{g} \cdot \mathrm{mL}^{-1}\right)\end{array}$ & Area & \\
\hline \multirow[b]{2}{*}{1} & 250 PPM & 9003119 & \multirow[b]{2}{*}{8813682} \\
\hline & 250 PPM & 8624246 & \\
\hline \multirow[b]{2}{*}{2} & 125 PPM & 4400212 & \multirow[b]{2}{*}{4394017} \\
\hline & 125 PPM & 4387823 & \\
\hline \multirow[b]{2}{*}{3} & 62.5 PPM & 1941353 & \multirow[b]{2}{*}{1941353} \\
\hline & 62.5 PPM & ------ & \\
\hline \multirow[b]{2}{*}{4} & 31.25 PPM & 1153925 & \multirow[b]{2}{*}{1172291} \\
\hline & 31.25 PPM & 1190658 & \\
\hline \multirow[b]{2}{*}{5} & 15.62 PPM & 590142 & \multirow[b]{2}{*}{587893} \\
\hline & 15.62 PPM & 585644 & \\
\hline 6 & \multicolumn{2}{|c|}{ Regression Equation } & $Y=35282 x-36065$ \\
\hline 7 & \multicolumn{2}{|c|}{ Correlation coefficient $\left(\mathrm{R}^{2}\right)$} & 0.9985 \\
\hline 8 & \multicolumn{2}{|c|}{ Std. Error of intercept } & 103116 \\
\hline 9 & \multicolumn{2}{|c|}{ Std. Dev. of intercept } & 230574.38 \\
\hline 10 & \multicolumn{2}{|l|}{ LOD } & $21.56 \mu \mathrm{g} \cdot \mathrm{ml}^{-1}$ \\
\hline 11 & \multicolumn{2}{|l|}{ LOQ } & $65.35 \mu \mathrm{g} \cdot \mathrm{ml}^{-1}$ \\
\hline
\end{tabular}

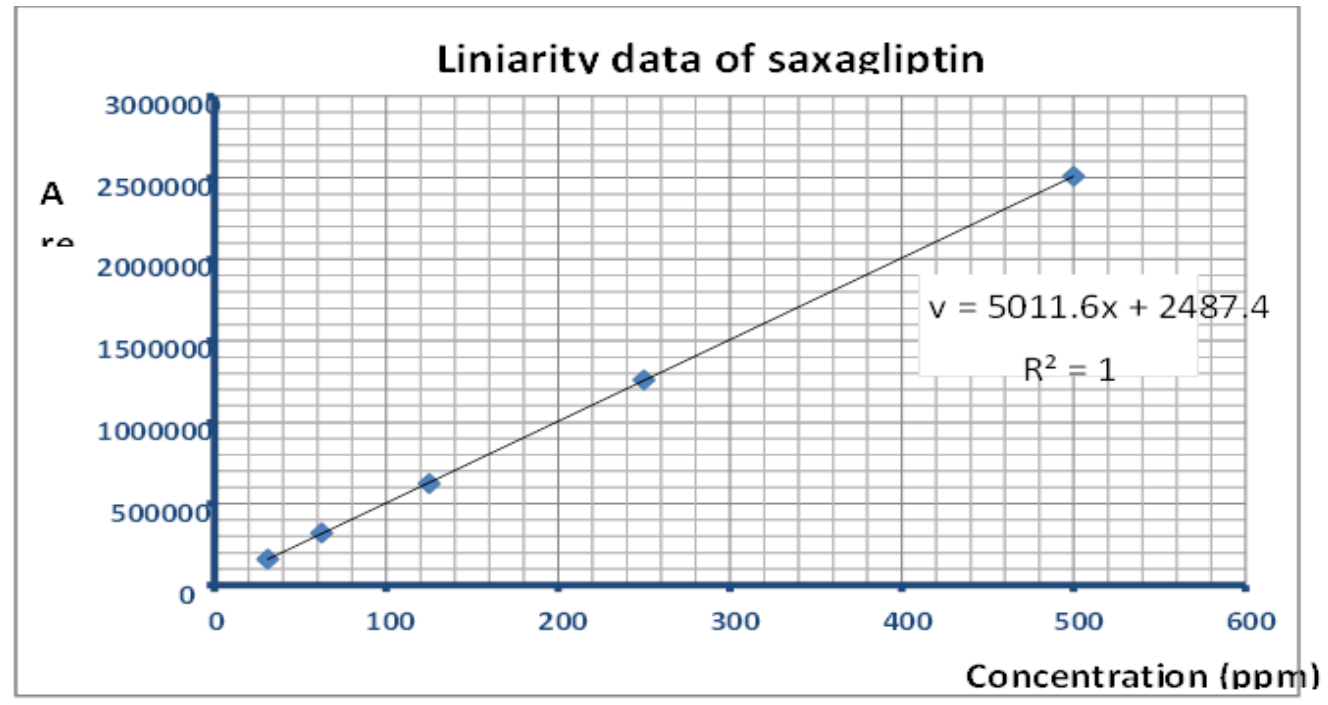

Figure 2 Calibration curve of sitagliptin 


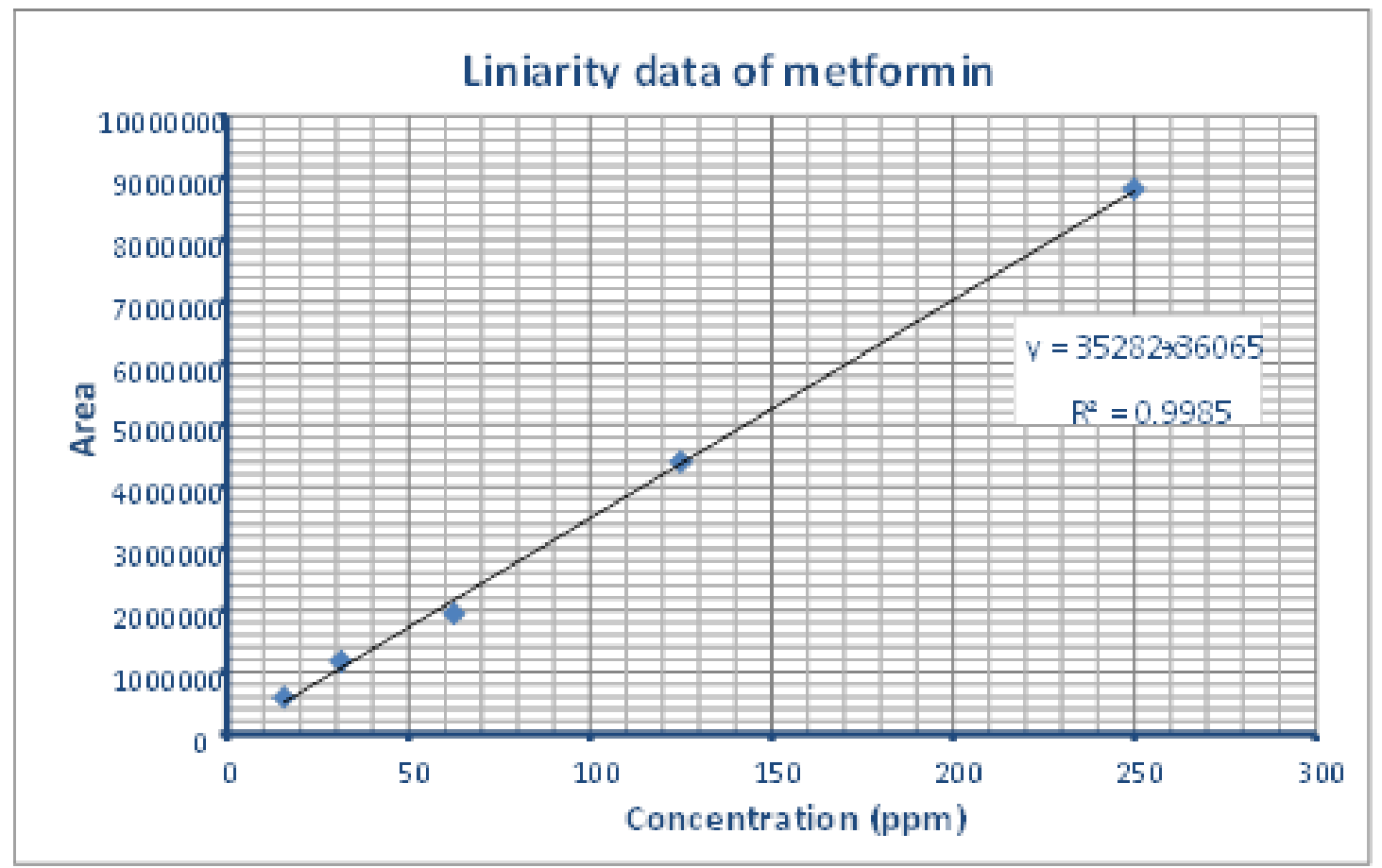

Figure 3 Calibration curve of metformin

\subsubsection{Robustness for the chromatographic method}

From the studies, after making deliberated changes in flow rate $( \pm 0.2 \mathrm{~mL} \cdot \mathrm{min}-1)$, organic modifier concentration; acetonitrile $( \pm 2 \%)$ and wavelength $( \pm 2 \mathrm{~nm})$ have not made any significant changes in resolution, capacity factor and tailing factor. Nonetheless, it seems minute changes in robustness studies makes significant changes in theoretical plate counts, Shown in (Figure 4 \& 5).

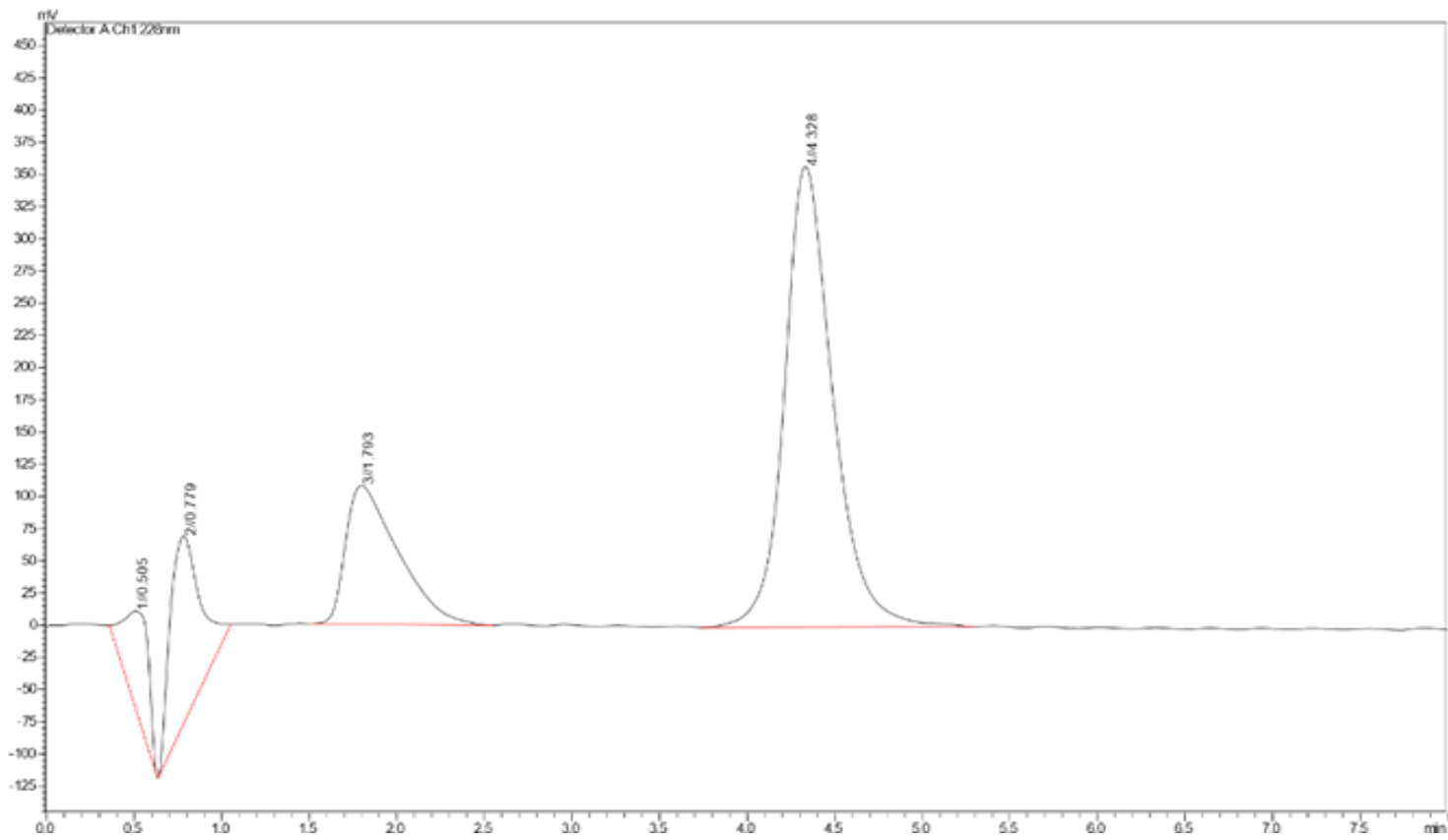

Figure 4 Robustness studies for SXP (1.79 $\mathrm{min}$ ) and MET (4.32 $\mathrm{min}$ ) at methanol 85\% 


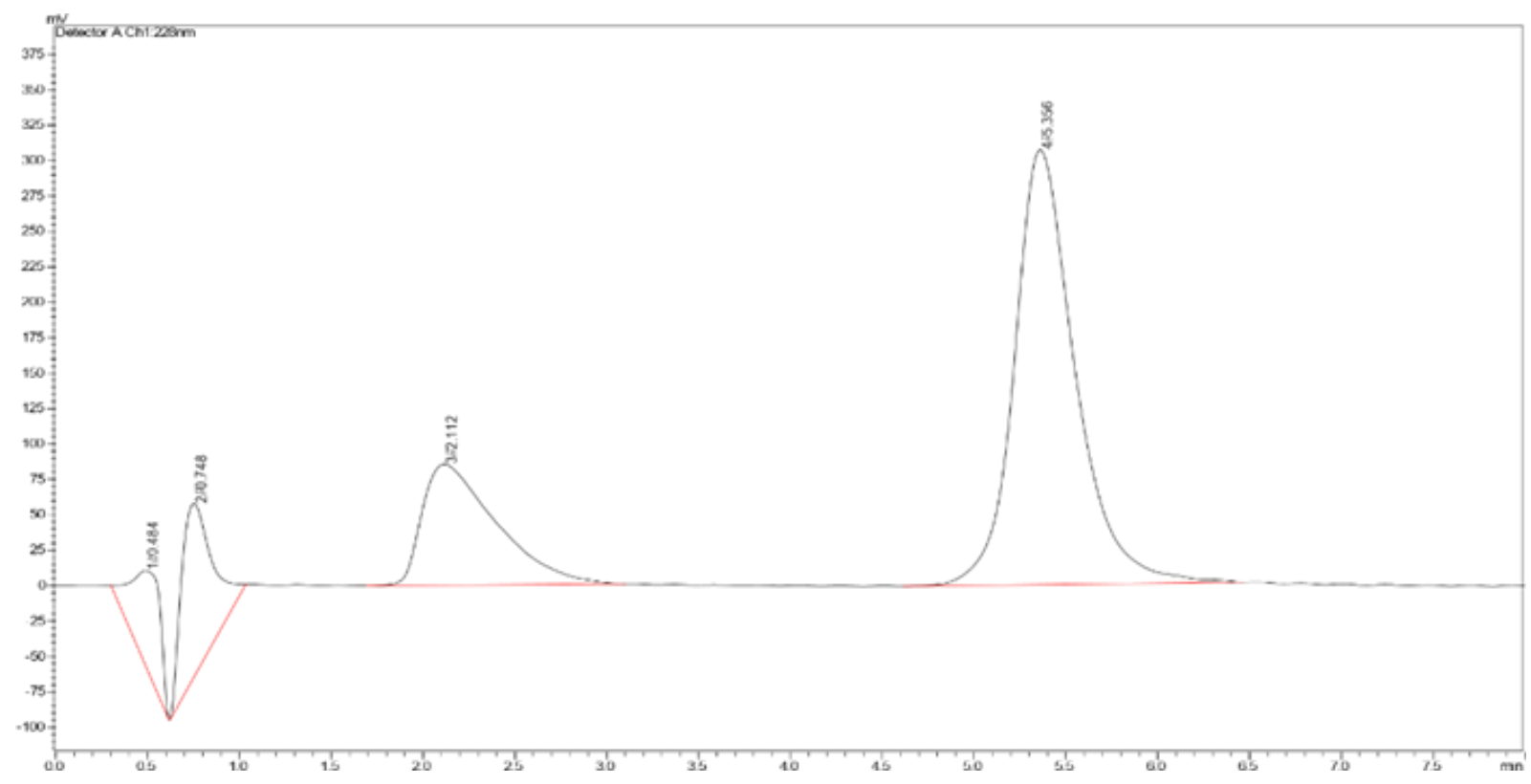

Figure 5 Robustness studies for SXP (2.11 min) and MET (5.35 min) at methanol 81\%

\subsubsection{Accuracy}

Accuracy of the results was calculated by $\%$ recovery of 5 different concentrations of each drug. Figure $6 \& 7$. The results including the mean of the recovery and standard deviation are shown in (Table 6 \& 7).

Table 6 Accuracy data of metformin (MET)

\begin{tabular}{|c|c|c|c|c|c|c|c|}
\hline Conc. (\%) & S. No. & $\begin{array}{l}\text { S. amt. amt. } \\
\left(\mu \mathrm{mg} \mathrm{L}^{-1}\right)\end{array}$ & $\begin{array}{l}\text { D. added } \\
\left(\mu \mathrm{g} \cdot \mathrm{mL}^{-1}\right)\end{array}$ & $\begin{array}{l}\text { Amt. rec. } \\
\left(\mu \mathrm{g} \cdot \mathrm{mL}^{-1}\right)\end{array}$ & $\%$ recovery & Mean \pm SD & \% RSD \\
\hline \multirow{3}{*}{$80 \%$} & 1 & 250 & 200 & 430.89 & 95.75 & \multirow{3}{*}{$96.78 \pm 1.20$} & \multirow{3}{*}{1.24} \\
\hline & 2 & 250 & 200 & 434.22 & 96.49 & & \\
\hline & 3 & 250 & 200 & 445.12 & 98.11 & & \\
\hline \multirow{3}{*}{$100 \%$} & 1 & 250 & 250 & 512.27 & 102.45 & \multirow{3}{*}{$98.70 \pm 3.30$} & \multirow{3}{*}{3.35} \\
\hline & 2 & 250 & 250 & 480.40 & 96.18 & & \\
\hline & 3 & 250 & 250 & 487.43 & 97.48 & & \\
\hline \multirow{3}{*}{$120 \%$} & 1 & 250 & 300 & 543.21 & 98.76 & \multirow{3}{*}{$99.32 \pm 0.90$} & \multirow{3}{*}{0.90} \\
\hline & 2 & 250 & 300 & 552.01 & 100.36 & & \\
\hline & 3 & 250 & 300 & 543.67 & 98.84 & & \\
\hline
\end{tabular}


Table 7 Accuracy data of saxagliptin (SXP)

\begin{tabular}{|c|c|c|c|c|c|c|c|}
\hline Conc. (\%) & S. No. & $\begin{array}{l}\text { S. amt. } \\
\left(\mu \mathrm{g} \cdot \mathrm{mL}^{-1}\right)\end{array}$ & $\begin{array}{l}\text { D. added } \\
\left(\mu \mathrm{g} \cdot \mathrm{mL}^{-1}\right)\end{array}$ & $\begin{array}{l}\text { Amt. rec. } \\
\left(\mu \mathrm{g} \cdot \mathrm{mL}^{-1}\right)\end{array}$ & $\begin{array}{l}\% \\
\text { recovery }\end{array}$ & Mean \pm SD & \% RSD \\
\hline \multirow{3}{*}{$80 \%$} & 1 & 2.5 & 2 & 4.36 & 96.88 & \multirow{3}{*}{$97.55 \pm 0.59$} & \multirow{3}{*}{0.60} \\
\hline & 2 & 2.5 & 2 & 4.40 & 97.78 & & \\
\hline & 3 & 2.5 & 2 & 4.41 & 98 & & \\
\hline \multirow{3}{*}{$100 \%$} & 1 & 2.5 & 2.5 & 5.10 & 102 & \multirow{3}{*}{$99.93 \pm 2.21$} & \multirow{3}{*}{2.21} \\
\hline & 2 & 2.5 & 2.5 & 5.01 & 100.2 & & \\
\hline & 3 & 2.5 & 2.5 & 4.88 & 97.6 & & \\
\hline \multirow{3}{*}{$120 \%$} & 1 & 2.5 & 3 & 5.30 & 96.36 & \multirow{3}{*}{$96.56 \pm 1.04$} & \multirow{3}{*}{1.08} \\
\hline & 2 & 2.5 & 3 & 5.36 & 97.69 & & \\
\hline & 3 & 2.5 & 3 & 5.26 & 95.63 & & \\
\hline
\end{tabular}

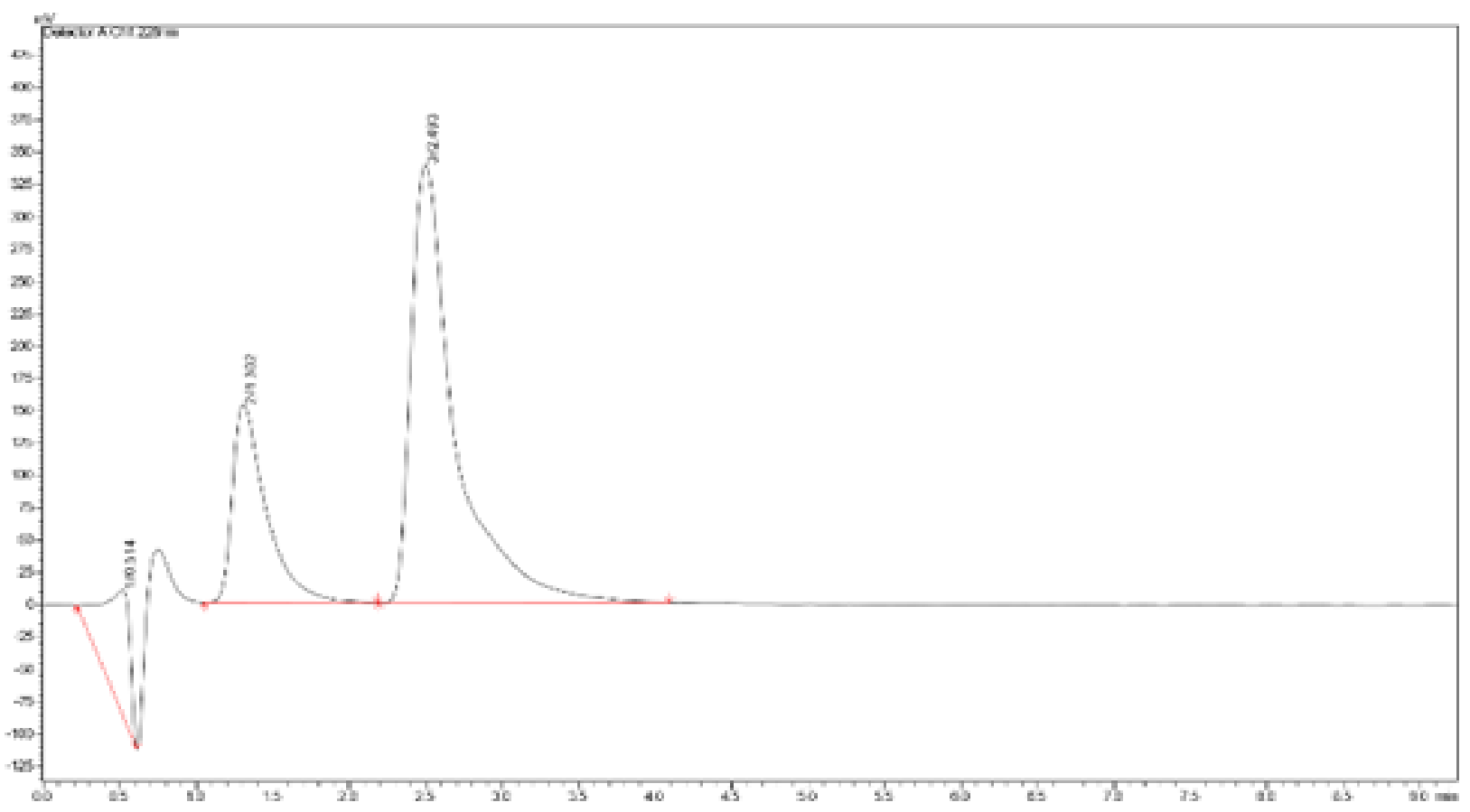

Figure 6 Accuracy data of SXP (1.30 min) and MET (2.49) at 80\% 


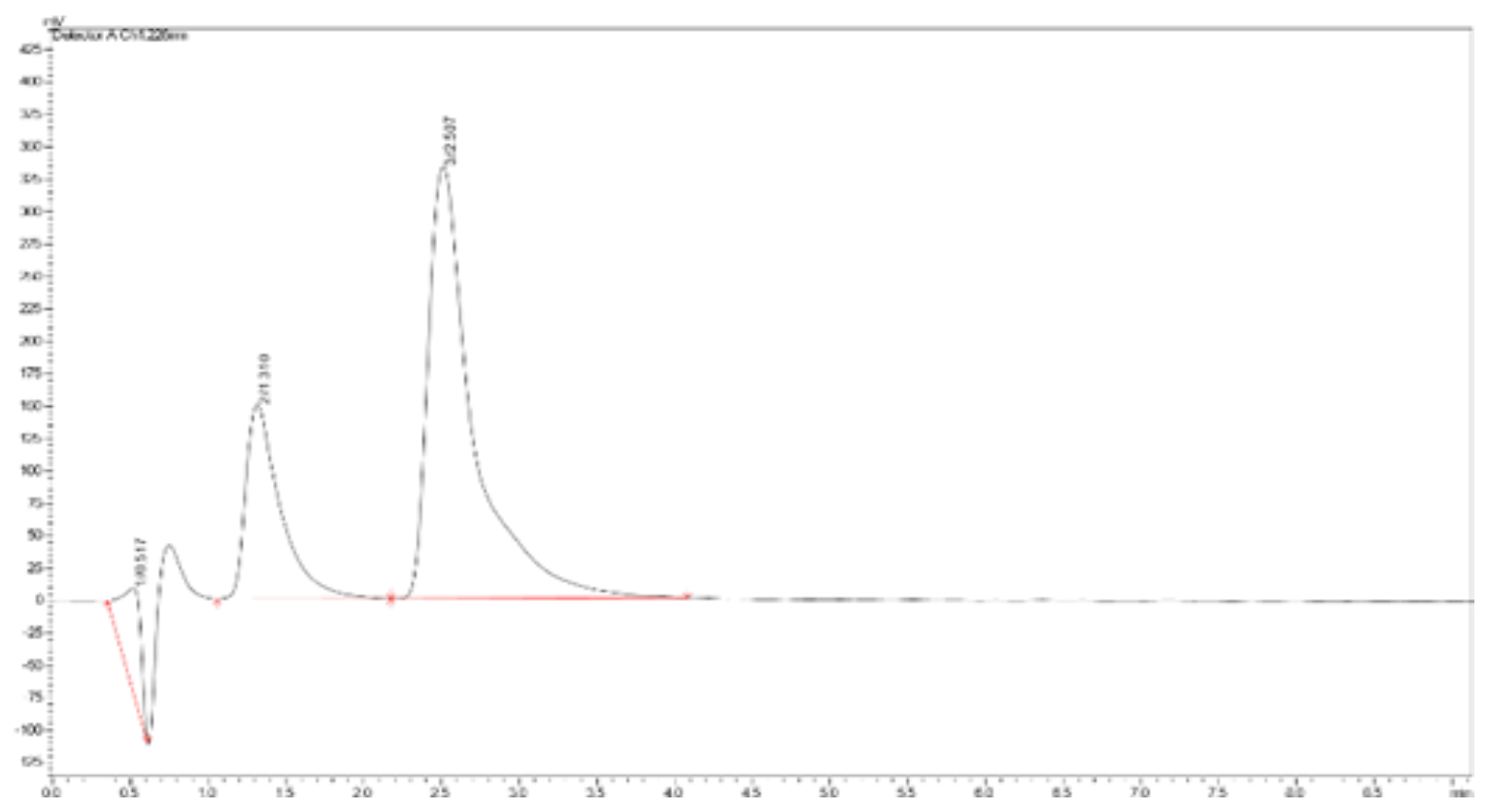

Figure 7 Accuracy data of SXP (1.31 min) and MET(2.50) at 120\%

\section{Discussion}

The proposed reverse phase chromatographic (RP-HPLC) analytical method for the simultaneous estimation of saxagliptin (SXP) and metformin (MET) in both bulk and tablet formulation have complied the ICH and US-FDA guidelines. As per the ICH and USFDA guidelines, the developed method has complied the linearity range (calibration data), accuracy/drug recovery studies (\%), repeatability, precision studies (intraday and interday/intermediate), and robustness. Moreover, as per the ICH guidelines, the system suitability test performed for simultaneous estimation of saxagliptin and metformin has achieved all guidelines; including, tailing factor $(\mathrm{T})$, separation factors $(\alpha)$, theoretical plates $(\mathrm{N})$, capacity factor $\left(\mathrm{k}^{\prime}\right)$, resolution $(\mathrm{R})$ and RSD (\%). In addition, the stability indicating studies or force degradation studies were also performed for both these drugs. As concluded, both drugs were seen stable in thermal, oxidation and acid induced hydrolysis.

\section{Conclusion}

Above all results we, may conclude that, this developed and validated method for investigation by reverse phase chromatography can be used for routine analysis of simultaneous estimation of either saxagliptin or metformin or both from the mixture of marketed formulation.

\section{Compliance with ethical standards}

\section{Acknowledgments}

I am thankful to Principal, Guide, Ms Swapnali Mankar and colleagues for providing technical support.

\section{Disclosure of conflict of interest}

All authors have no conflict of interest.

\section{References}

[1] Ulrich J, Michael T. Encyclopedia of physical science and enchology. 3rd ed. Analytical chemistry. 2001; 543-579.

[2] Mendum J, Denny RC, Thomas MN. Vogel's Textbook of Quantitative Analysis. 5th ed. New York: Pearson Education Ltd. 1994; 3. 
[3] Beckett AH, Stanlake JB. Practical Pharmaceutical Chemistry. 4th ed. Part 2. CBS Publishers and Distributors. 2002; 10.

[4] Corners' KA. Textbook of Pharmaceutical Analysis. 3rd ed. A Wiley Interscience Publication. $1999 ; 1$.

[5] Christian GD. Analytical Chemistry. 5th ed. John Wiley and Sons. Inc. 2003; 1-3.

[6] Sharma BK. Instrumental Methods of Chemical Analysis. Goel Publishing House, Meerut. 1983; 1-77.

[7] Watson DG. Pharmaceutical Analysis. 25th ed. Hart Court Publishers Limited, Livingstone. $2005 ; 3$.

[8] Mendum J, Denney RC, Barnes JD, Thomas M. Vogel's Textbook of Quantitative Analysis. 6th ed. Pearson Education, Singapore. 2003; 10.

[9] Khopkar SM. Basic concepts of analytical chemistry. New Age International Ltd. Publishers. 2nd ed. New Delhi. $1998 ; 2$.

[10] Skoog DA, Holler FJ, Crouch SR. Principle of Instrumental Analysis. Thomson Publications. 6th ed. India. $2007 ; 3$.

[11] Mendum J, Denny RC, Thomas MN. Vogel's Text Book of Quantitative Analysis. 5th ed. New York: Pearson Education Ltd. 1994; 10-11.

[12] Skoog DA, Holler FJ, Timothy A, Nieman NW. Principle of Instrumental Analysis. 5th ed. Eastern Press, Bangalore. 2004; 1-4, 729-732.

[13] Chatwal GR, Sharma A. Instrumental Methods of Chemical Analysis. 5th ed. Himalaya Publishing House, Delhi. $2004 ; 1.1-1.5$.

[14] Christian GD. In Analytical Chemistry. 6th ed. John Wiley and sons. 2003; 1-3.

[15] Jeffery GH, Bassat J, Mendham J, Denny RC. Vogel's Textbook of Quantitative Chemical Analysis. Elbs With Longman Publication. 5th ed. Harlow. 1989; 1, 3, 6.

[16] Willard HH, Merritt Jr. LL, Dean JA, Settle Jr. FA. Instrumental Methods of Analysis. CBS Publishers and Distributors. 7th ed. Delhi. 2001; 1.

[17] Carstensen JT, Rhodes CT. Drug Stability Principles and Practices. Vol. 107. Marcel Dekker Inc. 3rd ed. New York. 2002; 340-370.

[18] Pednekar S. Simultaneous Determination of Metformin, Sitagliptin, Saxagliptin, Linagliptin and Vildagliptin in Multicomponent Pharmaceutical Preparations by RP-HPLC. Chemistry. 2014; 12: 221-229.

[19] Çağlar S, Alp A. A Validated High-Performance Liquid Chromatography Method for the Determination of Saxagliptin and Metformin in Bulk, a Stability Indicating Study, Journal of Analytical and Bioanalytical Technologies. 2014; 8: 101-112. 